\title{
Biochemical Fractionation of Soil Organic Matter after Incorporation of Organic Residues
}

\author{
Serge-Étienne Parent, Léon E. Parent* \\ Department of Soils and Agrifood Engineering, Université Laval, Québec, Canada \\ Email: ${ }^{*}$ leon-etienne.parent@fsaa.ulaval.ca
}

Received 13 May 2015; accepted 12 June 2015; published 15 June 2015

Copyright (C) 2015 by authors and Scientific Research Publishing Inc.

This work is licensed under the Creative Commons Attribution International License (CC BY). http://creativecommons.org/licenses/by/4.0/

(c) (i) Open Access

\section{Abstract}

Soil organic matter (SOM) is a key factor for building and maintaining soil quality. The SOM quality is commonly assessed using densitometric and sieving separation methods, but such methods do not inform on the biochemical composition of SOM. Our objective was to evaluate the van Soest extraction procedure for soluble (SOL), holocellulose (HOLO) and lignin/cutin (LIC) fractions of SOM after incorporating crop residues and animal wastes into a C-depleted loamy sand. Millet cuttings, oat straw, fresh cattle manure and cattle manure compost were dried, sieved to obtain 53 250 and $250-2000 \mu \mathrm{m}$ size fractions and characterized biochemically using a modified NDF-ADFADL van Soest method. Soil was also sieved into 53 - 250 and 250 - $2000 \mu \mathrm{m}$ fractions. On a dry mass basis, crop residues contained $60 \%-70 \%$ holocellulose while animal wastes contained more than $40 \%$ ash. Each soil fraction was combined with three rates of the corresponding organic fraction $\left(2,4\right.$, and $6 \mathrm{Mg} \cdot \mathrm{ha}^{-1}$ millet forage cuttings or oat straw and 5, 10, and $15 \mathrm{Mg} \cdot \mathrm{ha}^{-1}$ of cattle manure or cattle manure compost). Changes in soil biochemical components were analyzed using the balance method of compositional data analysis. Amendment, application rate and size fraction influenced significantly $(p<0.05)$ the $[$ SOL $\mid$ HOLO] balance but did not significantly affect the [SOL,HOLO | LIC] balance. The [SOL | HOLO] increased linearly with addition rate of crop residues, and decreased linearly with addition rate of animal wastes. This approach of balancing biochemical SOM components is a promising method to monitor the changes in SOM quality after the incorporation of organic residues and to elaborate beneficial practices for managing crop residues and animal wastes in agro-ecosystems.

\section{Keywords}

Soil Organic Matter, Van Soest, Holocellulose, Lignin, Compositional Data Analysis

\footnotetext{
${ }^{*}$ Corresponding author.
} 


\section{Introduction}

Soil organic carbon (SOC) is the primary soil quality indicator driving soil chemical, biological, and physical functions [1]-[3]. The SOC decomposition rate depends on physical, chemical and biochemical protection mechanisms [4]. The physical protection to SOC against decomposition is provided by soil micro-aggregates $(<250$ $\mu \mathrm{m}$ in size) that are compact assemblages of mineral and organic matter [5]. The SOC models generally consider two or three biochemical C pools [6] [7]. The most labile SOC pools are sensitive indicators of soil biological activity [8] and structural stability [9] [10] resulting from agro-ecosystem management [11]-[14].

Labile and recalcitrant soil organic matter (SOM) fractions can be separated by size [15]. The particulate organic matter (POM) fraction is 53 to $2000 \mu \mathrm{m}$ in size and provides an estimate of labile C [16]. The POM often has a bulk density less than one [17] [18], hence facilitating densimetric separation, is high in C [19], and contains plant debris [20], hyphae, spores, seeds, faunal skeletons, microbial biomass and partially humified materials [21] that can be separated by sieving. The biochemical composition of POM requires analyzing POM using a biochemical fractionation procedure.

In general, organic matter added to soil is analyzed before incorporation. Its biochemical stability in soil is measured by incubation [7] [22]. The van Soest method [23] [24] which is a routine biochemical fractionation method of fiber analysis for neutral detergent fiber (NDF), acid detergent fiber (ADF) and acid detergent lignin (ADL) has been modified to analyze the biochemical composition of organic residues and composts before soil incorporation [22] [25] and can be expanded to analyze the biochemical composition of POM after incorporation of organic amendments into soil.

Our objective was to test the capacity of a modified van Soest method to characterize the biochemical composition of soil $\mathrm{C}$ after incorporation of organic amendments into soil with special attention to the 53 - 250 and 250 $2000 \mu \mathrm{m}$ POM fractions. In this experiment, we incorporate four organic sources at increasing rates into soil and determine the biochemical composition of mixtures.

\section{Material and Methods}

We sampled an Orthic Humo-ferric Podzol [26] sandy loam of the Ivry soil series collected on an experimental field at Saint-Ubalde de Portneuf, Quebec, Canada (46 $\left.{ }^{\circ} 45^{\prime} 23^{\prime \prime} \mathrm{N}, 1237^{\circ} 19^{\prime} 57^{\prime \prime} \mathrm{W}\right)$, containing 1.6\% SOM (550 ${ }^{\circ} \mathrm{C}$, $16 \mathrm{~h}$ ) in the $0-17 \mathrm{~cm}$ layer; $\mathrm{pH}\left(\mathrm{CaCl}_{2} 0.01 \mathrm{M}\right)$ was 5.2. In potato (Solanum tuberosum L.) crop systems, millet cuttings and oat straw, as well as cattle manure and manure compost, are often incorporated into soil. Samples of pearl millet (Pennisetum glaucum) forage cuttings, oat (Avena sativa L.) straw, cattle manure (feedlot) and cattle manure compost (field stored manure) were ground to $\leq 2 \mathrm{~mm}$ and sieved to obtain $53-250$ and $250-2000 \mu \mathrm{m}$ fractions of POM [27]. Millet forage has lowest LIC content due to mid-season sampling [28]. Cattle manure compost is presumably the most altered material. Soil particles were also separated into $53-250$ and $250-2000$ $\mu \mathrm{m}$ sieve-size fractions after shaking a mixture of soil and sodium hexametaphosphate $\left(5 \mathrm{~g} \cdot \mathrm{L}^{-1}\right)$ solution for 16 $\mathrm{h}$ at 360 strokes $\mathrm{min}^{-1}$. Each size fraction of organic residues was mixed with the same soil sieve-size fraction to represent the amount of soil mineral and organic fractions that could be recovered on the same sieve. Based on a soil bulk density of $1.32 \mathrm{~g} \cdot \mathrm{mL}^{-1}$ and an incorporation depth of $17 \mathrm{~cm}$, crop residues were added at rates of 2, 4, and $6 \mathrm{Mg} \cdot \mathrm{ha}^{-1}(0.0267,0.0534$ and $0.8010 \mathrm{~g}$ of plant residue per $30 \mathrm{~g}$ of soil, respectively) and animal wastes were incorporated at rates of 5,10 , and $15 \mathrm{Mg} \cdot \mathrm{ha}^{-1}(0.0677,0.1344$ and $0.2017 \mathrm{~g}$ per $30 \mathrm{~g}$ of soil), on a dry mass basis.

Fibers were extracted following the French standard XPU 44-162 of the van Soest procedure adapted to compost biochemical fractionation [22]. Briefly, $2.00 \pm 0.05 \mathrm{~g}$ of the soil/organics mixtures were weighed in F57 filter bags and placed into an Ankom ${ }^{200 / 220}$ fiber analyzer. At each extraction step, the ash content of residual matter was quantified. The proportion of soluble substances (SOL) was computed as \%SOM - \%NDF (neutral detergent fibers) and that of holocelullose as \%NDF - \%ADL; the residual lignin plus cutin fraction was reported as \%ADL (acid-digestible lignin). The recalcitrant LIC fraction was computed as \%SOM - \% $\%$ SO - \% HOLO. Because the LIC fraction is computed by difference, experimental errors must accumulate in the LIC fraction.

\section{Compositional Data Analysis}

Because biochemical compositions are constrained to $100 \%$ and one component is computed by difference, they 
convey important properties as follows: 1) the normality assumption-which scans the real space-is inappropriate because confidence intervals may reach beyond the compositional space, and 2) the covariance matrix is biased (if the proportion of a component increases, at least another must decrease) and spurious (the covariance depends on scale). As compositional data transformation method, the additive log dual ratio (alr) or log contrast between two proportions ( $c_{1}$ and $c_{2}$ ) has been first proposed based on the logistic distribution as follows [29]:

$$
\text { alr }=\ln \left(\frac{c_{1}}{c_{2}}\right)=\ln \left(c_{1}\right)-\ln \left(c_{2}\right)
$$

A D-part compositional vector has D-1 degrees of freedom [30] and can be expanded to a multiplicative logistic distribution [29]. To avoid biases when analyzing the biochemical fractions of maize mulch residues, [31] used orthonormal balances [32]. The isometric log ratio (ilr) provides D-1 orthonormal balances that allow avoiding biases when analyzing compositional data [32]. The ilr transformation is based on a system of balances formalized as a sequential binary partition (SBP), i.e. a $(D-1) \times D$ matrix, in which parts labeled " +1 ” (group numerator) are contrasted with parts labeled " -1 " (group denominator) in each ordered row. A part labeled " 0 " is excluded from the balance. The composition is partitioned sequentially at every ordered row into two contrasts until the $(+1)$ and $(-1)$ non-overlapping subsets each contain a single part. The ilr is a ratio of the geometric means of the $(+)$ and $(-)$ groups normalized by a coefficient, computed as follows [32]:

$$
i l r_{k}=\sqrt{\frac{r_{k} s_{k}}{r_{k}+s_{k}}} \ln \left(\frac{\left(c_{i_{1}} c_{i_{2}} \times \ldots \times c_{i_{r}}\right)^{\frac{1}{r_{k}}}}{\left(c_{j_{1}} c_{j_{2}} \times \ldots \times c_{j_{s}}\right)^{\frac{1}{s_{k}}}}\right)
$$

where, in the $k^{\text {th }}$ row of the SBP, $r_{k}$ is the number of proportions in the $(+)$ group, $s_{k}$ is the number of proportions in the minus (-) group, $c_{i_{n}}$ is the $n^{\text {th }}$ component in the $(+)$ group and $c_{i_{n}}$ is the $\mathrm{n}^{\text {th }}$ component in the (-) group. For example, the balance between the more labile fractions (SOL and HOLO) is computed as follows:

$$
[S O L \mid H O L O]=\sqrt{\frac{1 x 1}{1+1}} \ln \left(\frac{H O L O}{S O L}\right)
$$

The balance between the more labile (SOL and HOLO) and the more recalcitrant (LIC) fractions is computed as follows:

$$
[S O L, H O L O \mid L I C]=\sqrt{\frac{2 x 1}{2+1}} \ln \left(\frac{L I C}{\sqrt{S O L x H O L O}}\right)
$$

where SOL, HOLO, and LIC are proportions of each biochemical fractions of SOM expressed on a common basis (e.g. dry soil mass or organic mass). Note that balances are subcompositionally coherent, i.e. results are independent whether results are expressed relatively to the fresh, dry or organic mass. This is an important advantage of the balance over percentages that vary with scale (moist, wet or organic basis), because the analytical results can be interpreted coherently whatever the scale referential [33] [34]. Fractions on the left are at denominator and those on the right at numerator (Equation (1)) because in algebra, numbers are generally row-listed from the most negative to the most positive.

In this paper, we contrasted the labile SOM fractions (SOL, HOLO) with the more recalcitrant one (LIC), then SOL and HOLO fractions as follows: [HOLO,SOL | LIC] and [SOL | HOLO] (Figure 1).

\section{Statistical Analysis}

For each of the two soil fractions (53 - 250 and $250-2000 \mu \mathrm{m})$, there were three rates of organic residues of the corresponding sieve-size fraction. Each treatment was replicated nine times. The statistical setup was a completely random factorial design. The statistical analysis was performed using the [HOLO,SOL $\mid \mathrm{LIC}]$ and [SOL $\mid \mathrm{HOLO}]$ balances as response variables along a gradient of POM additions. Fixed descriptors were size fraction (53 - 250 and $250-2000 \mu \mathrm{m}$ ), source of organic residue (millet, oat manure, compost) and application rate (continuous variable). The model was computed in the R statistical environment [35] with the lme4 [36] and lmer Test [37] packages. Prior to analysis, outliers were discarded at the 0.05 level of significance using the voutlier package [38]. The compositions package [39] was used to transform percentages into ilrs, hence providing D-1 degrees of 


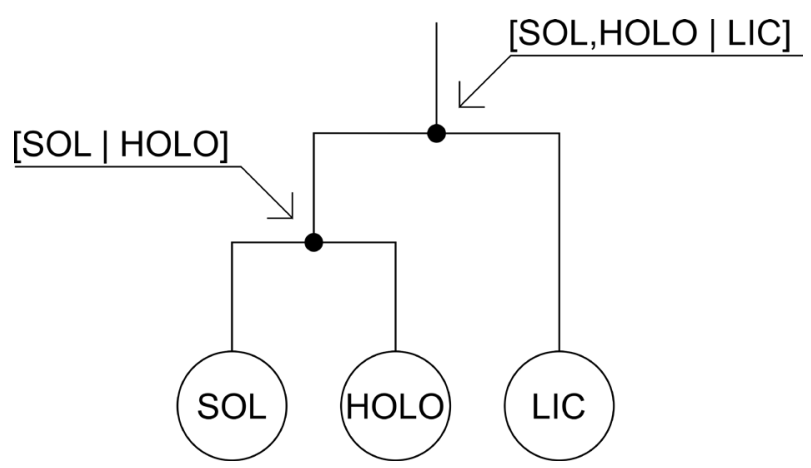

Figure 1. Balances between biochemical components.

freedom [40].

\section{Results}

\subsection{Organic Residues}

There was a large variation in biochemical fractions among organic residues and their size fractions expressed on either dry or organic mass basis while balances between biochemical components remained constant (Table 1). The correlation between biochemical fractions expressed on a soil or an organic mass varied from 0.47 (ns) for SOL to $0.75(\mathrm{p}<0.05)$ for LIC and $0.936(\mathrm{p}<0.01)$ for HOLO, indicating the large influence of ash content on the compositional vector. Balances thus avoid incoherence. Proportions computed on different bases that obviously return different results are referred to as "subcompositional incoherence" or scale dependency. However, the influence of the basis (dry soil or organic mass) is avoided by ratioing the proportions (e.g. [HOLO/SOM]/ $[\mathrm{SOL} / \mathrm{SOM}]=\mathrm{HOLO} / \mathrm{SOL}$ ) as shown on the right-hand side of Table 1 .

Balances between biochemical fractions expressed as isometric log ratios (Equations (2)-(4)) varied little in animal wastes, indicating that the manure compost was still immature despite partial composting in field piles. Indeed, the ilr transformation maps the dry mass composition from the three initial biochemical components (SOL, HOLO, LIC) in the compositional space to two orthonormal balances in the Euclidean space. Ash content was much lower in crop residues than animal wastes. Ash content was highest in the fine POM fraction of cattle manure, indicating mixture of manure with soil in the feedlot. Hence, the amounts of biochemical components added to soil were smaller in the fine than the coarse POM fractions. The advantage of orthonormal balances is shown here by the partitioning of organic and mineral components into linearly independent subsets.

The proportion of SOL was higher in the fine than the coarse POM fractions of crop residues, indicating that biochemical components were sorted out upon sieving. Compared to oat straw that was collected in the fall, the SOL fraction was higher and HOLO smaller in millet forage cuttings due to in-season sampling far from plantmaturity. Compared to their coarse POM fraction, the fine POM fraction of cattle manure and manure compost also appeared higher in SOL content.

\subsection{Soil-Residue Mixtures}

There were significant differences $(\mathrm{p} \leq 0.05)$ in biochemical composition of the mixtures between soil and organic amendments (Table 2). The SOL component varied with the size fraction. The HOLO fraction varied with the source of organic amendment, application rate as well as the size fraction and its interaction with the organic source. The LIC fraction varied with the source of organic amendment, the rate of application, the interaction between the source of amendment and the rate of application, and the interaction between the size fraction and the rate of application. However, as we recall from compositional data theory, the variance analyses computed across the inter-related SOL, HOLO and LIC proportions that have D-1 matrix rank are not statistically valid: the statistics should be interpreted from the balances between components, i.e. [SOL,HOLO | LIC] and [SOL HOLO], at fulcrum (Figure 1), as isometric log ratios between two geometric means (Equation (1)).

The [SOL,HOLO $\mid \mathrm{LIC}]$ balance of size fractions did not differ significantly $(\mathrm{p}<0.05)$ among treatments (Table 2). The $[\mathrm{SOL}, \mathrm{HOLO} \mid \mathrm{LIC}]$ balance thus appeared to be a poor indicator of SOM quality after incorporation 
Table 1. Average biochemical compositions and compositional balances of four organic residues.

\begin{tabular}{|c|c|c|c|c|c|c|c|}
\hline Organic residue & Sieve size & Ash & SOL & HOLO & LIC & \multicolumn{2}{|c|}{ Balances } \\
\hline \multicolumn{3}{|c|}{$\mu \mathrm{m}$} & & & & {$[\mathrm{SOL}, \mathrm{HOLO} \mid \mathrm{LIC}]$} & [SOL $\mid \mathrm{HOLO}]$ \\
\hline \multicolumn{8}{|c|}{$\%$ on dry matter basis } \\
\hline \multirow[t]{2}{*}{ Millet forage } & $2000-250$ & 16.6 & 18.1 & 60.8 & 4.5 & 1.632 & -0.858 \\
\hline & $250-53$ & 17.3 & 20.9 & 58.8 & 3.0 & 1.997 & -0.732 \\
\hline \multirow[t]{2}{*}{ Oatstraw } & $2000-250$ & 12.5 & 3.4 & 71.2 & 12.9 & 0.151 & -2.150 \\
\hline & $250-53$ & 12.7 & 8.9 & 69.8 & 8.5 & 0.877 & -1.455 \\
\hline \multirow[t]{2}{*}{ Cattlemanure } & $2000-250$ & 52.4 & 14.3 & 18.2 & 15.1 & 0.052 & -0.168 \\
\hline & $250-53$ & 87.6 & 6.4 & 3.3 & 2.7 & 0.436 & 0.461 \\
\hline \multirow[t]{2}{*}{ Manure compost } & $2000-250$ & 41.2 & 16.9 & 22.8 & 19.1 & 0.024 & -0.213 \\
\hline & $250-53$ & 47.8 & 27.5 & 12.1 & 12.5 & 0.308 & 0.579 \\
\hline \multicolumn{8}{|c|}{$\%$ on organicmatter basis } \\
\hline \multirow[t]{2}{*}{ Millet forage } & $2000-250$ & - & 21.7 & 72.9 & 5.4 & 1.632 & -0.858 \\
\hline & $250-53$ & - & 25.2 & 71.1 & 3.7 & 1.997 & -0.732 \\
\hline \multirow[t]{2}{*}{ Oatstraw } & $2000-250$ & - & 3.9 & 81.3 & 14.7 & 0.151 & -2.150 \\
\hline & $250-53$ & - & 10.2 & 80.0 & 9.8 & 0.877 & -1.455 \\
\hline \multirow[t]{2}{*}{ Cattlemanure } & $2000-250$ & - & 30.1 & 38.1 & 31.8 & 0.052 & -0.168 \\
\hline & $250-53$ & - & 51.4 & 26.8 & 21.8 & 0.436 & 0.461 \\
\hline \multirow[t]{2}{*}{ Manure compost } & $2000-250$ & - & 28.7 & 38.8 & 32.4 & 0.024 & -0.213 \\
\hline & $250-53$ & - & 52.7 & 23.3 & 24.0 & 0.308 & 0.579 \\
\hline
\end{tabular}

Table 2. Effects of organic residues, rate of application and particle size on proportions of organic and mineral pools and on compositional balances between biochemical pools. $\mathrm{SOL}=$ soluble; $\mathrm{HOLO}=$ holocellulose LIC $=$ lignin + cutin; $\mathrm{DMB}=$ dry mass basis.

\begin{tabular}{|c|c|c|c|c|c|}
\hline \multirow[t]{2}{*}{ Source of variation } & \multicolumn{3}{|c|}{ Proportion on DMB } & \multicolumn{2}{|c|}{ Balance } \\
\hline & SOL & HOLO & LIC & [SOL,HOLO | LIC] & {$[\mathrm{SOL} \mid \mathrm{HOLO}]$} \\
\hline Organics & ns & $* * *$ & * & ns & * \\
\hline Rate & ns & ${ }^{* * *}$ & $* *$ & ns & $*$ \\
\hline Size & ** & * & ns & ns & $* * *$ \\
\hline Organics: Rate & ns & $* * *$ & * & ns & $* * *$ \\
\hline Organics: Size & ns & ns & ns & ns & ns \\
\hline Rate: Size & ns & ns & * & ns & ns \\
\hline Organics: Rate: Size & ns & $\mathrm{ns}$ & ns & $\mathrm{ns}$ & $\mathrm{ns}$ \\
\hline
\end{tabular}

ns, ${ }^{*}$ and ${ }^{* *}$ : non-significant and significant at the $0.10,0.05$ and 0.01 levels, respectively.

of organic residues into soil. On the other hand, the organic amendment, application rate, size fraction and the interaction between the organic amendment and application rate influenced the [SOL | HOLO] balance significantly $(\mathrm{p} \leq 0.05)$. The SOL weighted more in the fine than the larger fraction as shown by a more negative $[\mathrm{SOL} \mid \mathrm{HOLO}]$ balance in the finer fraction. 
The $[\mathrm{SOL} \mid \mathrm{HOLO}]$ balance facilitated interpreting the results as shown by well-defined linear response trends upward for crop residues and downward for animal wastes (Figure 2). The [SOL | HOLO] balance decreased linearly with the addition rate of animal wastes due to a combination of higher SOL and lower HOLO contents in animal wastes (Table 1) resulting from feed digestion in the animal tract and partial decomposition in manure piles. Hence, compared to current laboratory methods and the ensuing statistical analysis distorted by raw compositions, a combination of the modified van Soest extraction method with tools of compositional data analysis proved to be useful in interpreting the changes in SOM quality after incorporating organic residues into soil.

\section{Discussion}

Soil organic carbon is protected through physical, chemical, and biochemical mechanisms [4]. This paper is a first attempt to provide a biochemical indicator of SOM quality measured as a log ratio between two operational pools using a van Soest procedure that has been modified to assess compost biological stability. Adding crop and animal residues to soil changed the operational biochemical pools of the new mixture. After incorporation of organic residues into SOM, the HOLO pool and the [SOL | HOLO] balance were found to be highly contrasting across size fractions but the direction of the change depended on the organic residue and the application rate. On the other hand, the functionality of biochemical pools must depend on the chemical make-up of their organic polymers and molecules and could be addressed in future research.

Organic residues and SOM are complex mixtures of organic molecules [41]. Organic C from fresh organic materials is labile and a small fraction accumulates as recalcitrant humus [42]. There are also products of intermediate decomposability or highly resistant to decomposition [43]. The SOL fraction of crop residues is a mixture of proteins, starch, lipids and other easily decomposable components while other fractions are specific to hemicelluloses, cellulose and lignin plus cutin, respectively [44]. The NDF may extract a large variety of soluble products [45] like phenolic compounds that color the extracting solution (yellow to brown color) and that may resist to decomposition. As a result, the SOL fraction could comprise both labile and recalcitrant C. The LIC fraction in the present study is an elusive component computed by difference that may contain plant lignin and cutin as well as recalcitrant humic substances and humin. Although humic substances are generally associated with the soil mineral fractions [8] [14] [46], NDF soluble humic substances from SOM may swamp out NDF soluble materials from organic residues. The HOLO fraction is the most specific one. The HOLO and the labile part of SOL could be considered as proxies for labile C pools. However, the van Soest method did not allow separating the labile from the recalcitrant $\mathrm{C}$ forms in the SOL fraction while a SOM quality index must take into account the compositional nature of biochemical fractions. Balances are computed as isometric log ratios to avoid redundancy (three components closed to $100 \%$ SOM are reduced to two linearly independent variables) and confusing scale dependency (the ratios eliminate the basis as soil dry mass or organic mass that return different proportions from the same analytical results). The [SOL | HOLO] balance computed using Equation 3 proved to be a biochemical POM index that can be detected by the modified van Soest method. Because a single balance proved to be significant, the distance between two compositions can be computed as a difference between two log ratios (Equations 1 or 3) rather than a Euclidean distance across two or more orthonormal balances.

Existing fractionation methods are divided into physical and chemical fractionation, which are based on different scopes regarding the mechanisms of SOC stabilization [47]. The POM is a SOM quality indicator sensi-

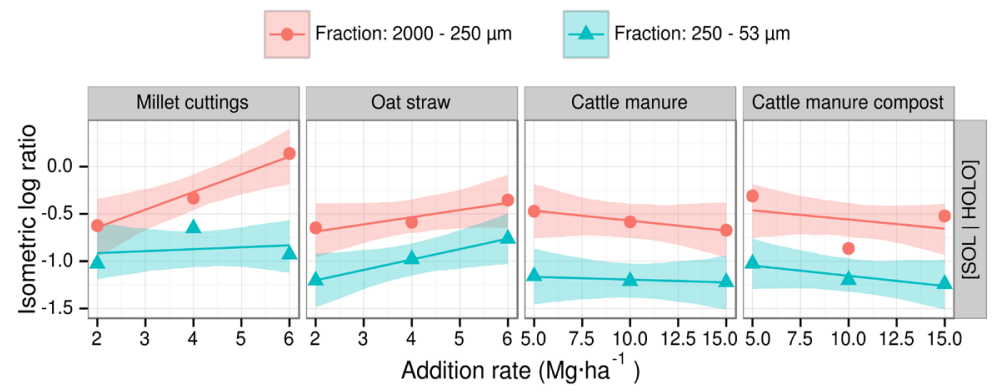

Figure 2. Change inthe [SOL | HOLO] balance with addition rates of organic residues in soil size fractions. Error ribbons reflect the precision of the isometric log ratio prediction at a 0.05 level. 
tive to changes in $\mathrm{C}$ inputs [48]. In a mechanistic approach to soil $\mathrm{C}$ sequestration, [4] [49] suggested that SOC fractions have their own specific saturation capacity in the soil. In support of this theory, [50] found evidence of soil $\mathrm{C}$ saturation of chemically and biologically protected $\mathrm{C}$ pools far from their theoretical $\mathrm{C}$ saturation, while saturation of physically protected $\mathrm{C}$ occurred closer to their $\mathrm{C}$ saturation level. However, a mechanistic explanation of a saturation level is still required for the unprotected and the biochemically protected C pools [49]. Loose terms such as "recalcitrance', the vague definitions for fractions such as particulate organic matter (POM) or mineral-associated organic matter (MOM) and poorly defined fractionation procedures have confused the discussion on SOM [47]. Although this research did not address the functionality of the operationally derived [SOL [HOLO] balance, it showed that the van Soest method modified for compost analysis can detect the changes in SOM quality and thus has the potential to assist modeling changes in biochemical $\mathrm{C}$ pools in soil particle-size fractions as driven by crop residues and animal wastes management.

\section{Conclusions}

A sensitive biochemical SOM quality index supported by a laboratory method could contribute to elaborating theories on $\mathrm{C}$ sequestration and cycling in soils and beneficial practices for managing crop residues and animal wastes in agro-ecosystems. The van Soest method detected changes in SOM quality in the 53 - 250 and 250 $2000 \mu \mathrm{m}$ fractions after mixing a C-depleted acid sandy loam soil with 2 to $6 \mathrm{Mg} \cdot \mathrm{ha}^{-1}$ of crop residues or 5 to 15 $\mathrm{Mg} \cdot \mathrm{ha}^{-1}$ of animal wastes. The [SOL | HOLO] balance computed as an isometric log ratio was found to respond linearly to additions of crop residues and animal wastes across size fractions.

The van Soest method could be tested on other soils using a larger spectrum of organic products and cultural practices because such method had the potential to monitor changes in SOM quality following residue management practices. The change in [SOL | HOLO] balance could be related to soil properties and functions to improve SOM management in agro-ecosystems.

\section{Acknowledgements}

This project is part of a more extensive project entitled "Implementing Means to Increase Potato Ecosystem Services" supported financially by the Natural Sciences and Engineering Council of Canada (CRDPJ 385199-09) and the following Canadian farm partners: Cultures Dolbec Inc., St-Ubalde, Québec; Groupe Gosselin FG Inc., Pont Rouge, Québec; Agriparmentier Inc. and Prochamps Inc., Notre-Dame-du-Bon-Conseil, Québec; Ferme Daniel Bolduc et Fils Inc., Péribonka, Québec.

\section{References}

[1] Doran, J.W. and Parkin, T.B. (1994) Defining and Assessing Soil Quality. In: Doran, J.W., Coleman, D.C., Bezdicek, D.F.and Stewart, B.A., Eds., Defining Soil Quality for a Sustainable Environment, Soil Science Society of America Journal, Madison, 3-21.

http://dx.doi.org/10.2136/sssaspecpub35.c1

[2] Louwagie, G., Gay, S.H. and Burrell, A. (2009) Addressing Soil Degradation in EU Agriculture: Relevant Processes, Practices and Policies. Report on the Project Sustainable Agriculture and Soil Conservation (SoCo), European Communities. http://eusoils.jrc.ec.europa.eu/esdb_archive/eusoils_docs/other/EUR23767.pdf

[3] Weil, R.R. and Magdoff, F. (2004) Significance of Soil Organic Matter to Soil Quality and Health. In: Magdoff, F. and Weil, R.R., Eds., Soil Organic Matter in Sustainable Agriculture, CRC Press, Boca Raton, 1-43. http://dx.doi.org/10.1201/9780203496374.ch1

[4] Stewart, C.E., Paustian, K., Conant, R.T., Plante, A.F. and Six, J. (2007) Soil Carbon Saturation: Concept, Evidence and Evaluation. Biogeochemistry, 86, 19-31. http://dx.doi.org/10.1007/s10533-007-9140-0

[5] Tisdall, J.M. and Oades, J.M. (1982) Organic Matter and Water-Stable Aggregates in Soils. Journal of Soil Science, 33, 141-163. http://dx.doi.org/10.1111/j.1365-2389.1982.tb01755.x

[6] Andrén, O. and Kätterer, T. (1997) ICBM: The Introductory Carbon Balance Model for Exploration of Soil Carbon Balances. Ecological Applications, 7, 1226-1236. http://dx.doi.org/10.1890/1051-0761(1997)007[1226:ITICBM]2.0.CO;2

[7] Thuriès, L., Pansu, M., Feller, C., Herrmann, P. and Rémy, J.C. (2001) Kinetics of Added Organic Matter Decomposition in a Mediterranean Sandy Soil. Soil Biology and Biochemistry, 33, 997-1010. http://dx.doi.org/10.1016/S0038-0717(01)00003-7 
[8] Gregorich, E.G. and Janzen, H.H. (1996) Storage of Soil Carbon in the Light Fraction and Macro-Organic Matter. In: Carter, M.R. and Stewart, B.A., Eds., Structure and Soil Organic Matter Storage in Agricultural Soils, CRC Press, Boca Raton, 167-190.

[9] Haynes, R.J. and Beare, M.H. (1996) Aggregation and Organic Matter Storage in Mesothermal, Humid Soils. In: Carter, M.R. and Stewart, B.A., Eds., Structure and Soil Organic Matter Storage in Agricultural Soils, CRC Press, Boca Raton, 213-262.

[10] Janzen, H.H., Campbell, C.A., Ellert, B.H. and Bremer, E. (1997) Soil Organic Matter Dynamics and Their Relationship to Soil Quality. In: Gregorich, E.G. and Carter, M.R., Eds., Soil Quality for Crop Production and Ecosystem Health, Elsevier Science, Amsterdam, 277-291. http://dx.doi.org/10.1016/s0166-2481(97)80039-6

[11] Cambardella, C.A. and Elliott, E.T. (1992) Particulate Soil Organic-Matter Changes across a Grassland Cultivation Sequence. Soil Science Society of America Journal, 56, 777-783. http://dx.doi.org/10.2136/sssaj1992.03615995005600030017x

[12] Campbell, C.A., Biederbeck, V.O., Wen, G., Zentner, R.P., Schoenau, J. and Hahn, D. (1999) Seasonal Trends in Selected Soil Biochemical Attributes: Effects of Crop Rotation in the Semiarid Prairie. Canadian Journal of Soil Science, 79, 73-84. http://dx.doi.org/10.4141/S98-008

[13] Graham, M.H., Haynes, R.J. and Meyer, J.H. (2002) Soil Organic Matter Content and Quality: Effects of Fertilizer Applications, Burning and Trash Retention on a Long-Term Sugarcane Experiment in South Africa. Soil Biology and Biochemistry, 34, 93-102. http://dx.doi.org/10.1016/S0038-0717(01)00160-2

[14] Wander, M. and Nissen, T. (2004) Value of Soil Organic Carbon in Agricultural Lands. Mitigation and Adaptation Strategies for Global Change, 9, 417-431. http://dx.doi.org/10.1023/B:MITI.0000038847.30124.77

[15] Balesdent, J. (1996) Un point sur l'évolution des réserves organiques des sols de France. Étude et Gestion des Sols, 3, 245-260.

[16] Cambardella, C.A., Gajda, A.M., Doran, J.W., Wienhold, B.J. and Kettler, T.A. (2001) Estimation of Particulate and Total Organic Matter by Weight Loss-on-Ignition. In: Lal, R., Kimble, J.M., Follett, R.F. and Stewart, B.A., Eds., Assessment Methods for Soil Carbon, Advances in Soil Science, CRC Press, Boca Raton, 349-359.

[17] Guggenberger, G. and Zech, W. (1999) Soil Organic Matter Composition under Primary Forest, Pasture, and Secondary Forest Succession, Region Huetar Norte, Costa Rica. Forest Ecology and Management, 124, 93-104. http://dx.doi.org/10.1016/S0378-1127(99)00055-9

[18] Six, J., Elliott, E.T., Paustian, K. and Doran, J.W. (1998) Aggregation and Soil Organic Matter Accumulation in Cultivated and Native Grassland Soils. Soil Science Society of America Journal, 62, 1367-1377. http://dx.doi.org/10.2136/sssaj1998.03615995006200050032x

[19] Carter, M.R., Gregorich, E.G., Angers, D.A., Donald, R.G. and Bolinder, M.A. (1998) Organic C and N Storage, and Organic C Fractions, in Adjacent Cultivated and Forested Soils of Eastern Canada. Soil and Tillage Research, 47, 253261. http://dx.doi.org/10.1016/S0167-1987(98)00114-7

[20] Skjemstad, J.O., Lefeuvre, R.P. and Prebble, R.E. (1990) Turnover of Soil Organic Matter under Pasture as Determined by ${ }^{13} \mathrm{C}$ Natural Abundance. Australian Journal of Soil Research, 28, 267-276. http://dx.doi.org/10.1071/SR9900267

[21] Baldock, J.A., Oades, J.M., Waters, A.G., Peng, X., Vassallo, A.M. and Wilson, M.A. (1992) Aspects of the Chemical Structure of Soil Organic Materials as Revealed by Solid-State Carbon-13 NMR Spectroscopy. Biogeochemistry, 16, 142. http://dx.doi.org/10.1007/BF02402261

[22] Lashermes, G., Nicolardot, B., Parnaudeau, V., Thuriès, L., Chaussod, R., Guillotin, M.L., Linères, M., Mary, B., Metzger, L., Morvan, T., Tricaud, A., Villette, C. and Houot, S. (2009) Indicator of Potential Residual Carbon in Soils after Exogenous Organic Matter Application. European Journal of Soil Science, 60, 297-310. http://dx.doi.org/10.1111/j.1365-2389.2008.01110.x

[23] Van Soest, P.J. and Wine, R.H. (1967) Use of Detergents in the Analysis of Fibrous Feeds. IV. Determination of Plant Cell-Wall Constituents. Journal of the Association of Official Analytical Chemists, 50, 50-55.

[24] Van Soest, P.J. and Wine, R.H. (1968) Determination of Lignin and Cellulose in Acid-Detergent Fiber with Permanganate. Journal of the Association of Official Analytical Chemists, 51, 780-785.

[25] Gabrielle, B., Da-Silveira, J., Houot, S. and Francou, C. (2004) Simulating Urban Waste Compost Effects on Carbon and Nitrogen Dynamics Using a Biochemical Index. Journal of Environmental Quality, 33, 2333-2342. http://dx.doi.org/10.2134/jeq2004.2333

[26] Soil Classification Working Group (1998) The Canadian System of Soil Classification. 3rd Edition, Agriculture and Agri-Food Canada Publications, Ottawa, 1646.

[27] Gregorich, E.G. and Beare, M.H. (2007) Physically Uncomplexed Organic Matter. In: Carter, M.R. and Gregorich, E.G., Eds., Soil Sampling and Methods of Analysis, 2nd Edition, CRC Press, Boca Raton, 1262. 
[28] Morales, J.U., Alatorre, A.H., Escalante, A.A., Lopez, S.B., Vazquez, H.G. and Gomez, M.O.D. (2011) Nutritional Characteristics of Silage and Hay of Pearl Millet at Four Phonological Stages. Journal of Animal and Veterinary Advances, 10, 1378-1382. http://dx.doi.org/10.3923/javaa.2011.1378.1382

[29] Aitchison, J. (1986) The Statistical Analysis of Compositional Data. Chapman and Hall, London. http://dx.doi.org/10.1007/978-94-009-4109-0

[30] Aitchison, J. and Greenacre, M. (2002) Biplots of Compositional Data. Journal of the Royal Statistical Society: Series C (Applied Statistics), 51, 375-392. http://dx.doi.org/10.1111/1467-9876.00275

[31] Aslam, S., Garnier, P., Rumpel, C., Parent, S.-É. and Benoit, P. (2013) Adsorption and Desorption Behavior of Selected Pesticides as Influenced by Decomposition of Maize Mulch. Chemosphere, 91, 1447-1455. http://dx.doi.org/10.1016/j.chemosphere.2012.12.005

[32] Egozcue, J.J. and Pawlowsky-Glahn, V. (2005) Groups of Parts and Their Balances in Compositional Data Analysis. Mathematical Geology, 37, 795-828. http://dx.doi.org/10.1007/s11004-005-7381-9

[33] Abdi, D., Cade-Menun, B.J., Ziadi, N. and Parent, L.-É. (2015) Compositional Statistical Analysis of Soil 31P-NMR Forms. Geoderma, in Press.

[34] Parent, S.-É., Parent, L.E., Rozane, D.-E., Hernandes, A. and Natale, W. (2012) Nutrient Balance as Paradigm of Soil and Plant Chemometrics. In: Issaka, R.N., Ed., Soil Fertility, InTech, Rijeka, Croatia, 83-114.

[35] R Core Team (2015) R: A Language and Environment for Statistical Computing.

[36] Bates, D., Maechler, M., Bolker, B. and Walker, S. (2014). Lme4: Linear Mixed-Effects Models Using Eigen and S4. Journal of Statistical Software, E-Print.

[37] Kuznetsova, A., Brockhoff, P.B. and Bojesen Christensen, R.H. (2015) LmerTest: Tests in Linear Mixed Effects Models.

[38] Filzmoser, P. and Gschwandtner, M. (2015) Mvoutlier: Multivariate Outlier Detection Based on Robust Methods.

[39] Van den Boogaart, K.G., Tolosana-Delgado, R. and Bren, M. (2014) Compositions: Compositional Data Analysis.

[40] Greenacre, M. (2011) Measuring Subcompositional Incoherence. Mathematical Geosciences, 43, 681-693. http://dx.doi.org/10.1007/s11004-011-9338-5

[41] Paul, E.A. and Clark, F.E. (1996) Soil Microbiology and Biochemistry. 2nd Edition, Academic Press, London.

[42] Robert, M. (2001) Soil Carbon Sequestration for Improved Land Management. Rome. ftp://ftp.fao.org/agl/agll/docs/wsrr96e.pdf

[43] Haynes, R.J. (2005) Labile Organic Matter Fractions as Central Components of the Quality of Agricultural Soils: An Overview. Advances in Agronomy, 85, 221-268. http://dx.doi.org/10.1016/s0065-2113(04)85005-3

[44] Francou, C. (2003) Stabilisation de la matière organqiue au cours du compostage de déchets urbains: Influence de la nature des déchets et du procédé de compostage-Recherche d'indicateurs pertinents. Ec. Dr. ABIES. Institut National Agronomique Paris-Grignon. https://tel.archives-ouvertes.fr/file/index/docid/47348/filename/tel-00007519.pdf

[45] Robin, D. (1997) Intérêt de la caractérisation biochimique pour l'évaluation de la proportion de matière organique stable après décomposition dans le sol et la classification des produits organominéraux. Agronomie, 17, 157-171. http://dx.doi.org/10.1051/agro:19970303

[46] Hayes, M.H.B. and Clapp, C.E. (2001) Humic Substances: Considerations of Compositions, Aspects of Structure, and Environmental Influences. Soil Science, 166, 723-737. http://dx.doi.org/10.1097/00010694-200111000-00002

[47] Poeplau, C., Don, A., Dondini, M., Leifeld, J., Nemo, R., Schumacher, J., Senafati, N. and Wiesmeier, M. (2013) Reproductibility of a Soil Organic Carbon Fractionation Method to Derive RothC Carbon Pools. European Journal of Soil Science, 64, 735-746. http://dx.doi.org/10.1111/ejss.12088

[48] Carter, M.R. (2002) Soil Quality for Sustainable Land Management: Organic Matter and Aggregation Interactions That Maintain Soil Functions. Agronomy Journal, 94, 38-47. http://dx.doi.org/10.2134/agronj2002.0038

[49] Six, J., Conant, R.T., Paul, E.A. and Paustian, K. (2002) Stabilization Mechanisms of Soil Organic Matter: Implications for C-Saturation of Soils. Plant and Soil, 241, 155-176. http://dx.doi.org/10.1023/A:1016125726789

[50] Stewart, C.E., Plante, A.F., Paustian, K., Conant, R.T. and Six, J. (2008) Soil Carbon Saturation: Linking Concept and Measurable Carbon Pools. Soil Science Society of America Journal, 72, 379-392. http://dx.doi.org/10.2136/sssaj2007.0104 